\title{
A Review of Syllabus: The Remarkable, Unremarkable Document that Changes Everything
}

By William Germano and Kit Nicholls, 2020. Princeton University Press. [ISBN: 9780691192208. 232 pages.]

\section{Reviewed by Andrea Williams, University of Toronto}

You may have seen or even shown your students the video of rapper Snoop Dogg that circulated last fall imploring college students to read the course syllabus, "you gotta do it, you gotta read it...the more you know the further you go." The brainchild of Benny $\mathrm{Ng}$, professor of chemistry at Pierce College in Los Angeles, the video was a playful response to a serious source of frustration for college teachers: ${ }^{1}$ most of our students don't seem to read one of the most important teaching documents we create. Although the idea that students should read course syllabuses ${ }^{2}$ is hardly controversial, some might balk at the prospect of an entire book devoted to the subject. Yet those of us interested in teaching genres, an eclectic group that includes not only WAC/WID and composition scholars, but also researchers in teaching and learning, educational developers, and administrators, understand the need for a closer examination of this document.

I thus approached Syllabus with a mix of curiosity and envy, the latter because Germano and Nicholls, professors of English at Cooper Union in New York City, have found that holy grail of recent scholarship: the hidden-in-plain-sight object of inquiry that is freighted with meaning. Much like recent books about everyday commodities such as salt, sugar, and chocolate that explore the profound cultural and economic impacts of these products, the title, Syllabus: The Remarkable, Unremarkable Document that Changes Everything captures the paradox of a document that is ubiquitous and often mundane, influential yet largely ignored (and not just by students). "Read the syllabus" is a refrain seen in merchandise, cartoons, and memes and the most common lament of higher education professionals, according to Kevin Gannon (2020). However, Gannon says it is instructors and not students who are to blame for "syllabus illiteracy," calling us "architects of our own frustrations" (p. 97) by not creating a document worth reading. Similarly, Germano and Nicholls claim that if students are not reading the syllabus, then we need to rethink how we write and teach with this document. Their book provides a map for how to do this work.

Rather than offering a history of the syllabus, which awaits other scholars, Germano and Nicholls craft a powerful and unabashedly entertaining argument (an impressive feat for a book about a document that is often deadly boring) about how we can use our syllabuses ${ }^{3}$ to improve our teaching and our students' learning. The authors promise "to take...that almost invisible bureaucratic document and use it to consider students' learning, students' lives” (p. xx), and they mostly make good on this claim. Locating the syllabus at the crossroads of aspirations and constraints, "where philosophical ambitions and epistemological assumptions meet next week's reading assignment and prep for a midterm" (p. 12), Germano and Nicholls invite us to reimagine our teaching, moving from the actual, "the syllabus we have" (p. 5), to the visionary, "the syllabus we could have" (p. 11).

Across the Disciplines

wac.colostate.edu/atd

A Journal of Language, Learning and Academic Writing

ISSN 554-8244

https://doi.org/10.37514/ATD-J.2022.18.3-4.09

Across the Disciplines is an open-access, peer-reviewed scholarly journal published on the WAC Clearinghouse and supported by Colorado State University and Georgia Southern University. Articles are published under a Creative Commons BY-NC-ND license (Attribution-NonCommercial-NoDerivs) ISSN 1554-8244. Copyright (C) 1997-2022 The WAC Clearinghouse and/or the site's authors, developers, and contributors. Some material is used with permission. 
Rather than recommend scavenger hunts, quizzes, videos by famous rappers, and other strategies (or gimmicks, depending on your perspective) that encourage students to read the syllabus, Germano and Nicholls argue for teachers to stop writing syllabuses as if they are merely contracts-resulting in anodyne boilerplate-and instead write syllabuses as teaching and learning tools that better reflect our courses and help engage students. Rather than blaming students for failing to extract key information from the syllabus, Germano and Nicholls assume students to be well-intentioned people for whom the syllabus (and, by extension, the work of one course) is competing with other commitments. They gently rebuke teachers who are not student-centered, arguing that “a syllabus isn't so much about what you will do. It's about what your students will do" (p. 5), arguing that responsibility for getting students to take the syllabus seriously lies primarily with teachers. If we fail to write a syllabus that accurately reflects our course goals and valuesfor example, if we include readings or assignments that are incompatible with them-then we signal, however unwittingly, that our syllabus is not to be trusted.

Germano and Nicholls' approach squares with the aims of the WAC movement: assignments are the "creative center of our teaching practice" (p.110) around which a syllabus should create a structure in which "somebody who doesn't yet understand what good work looks like in your discipline [can] build the curiosity, technique, habits, and understanding to do that work" (p. 15), and writing is central to the course design process of creating a syllabus. The authors' question, "why don't we talk about the syllabus as an occasion of 'writing to learn' for teachers?" (p. 16) is one of several that highlight the transformative potential of assignments and syllabuses. Few humanities scholars would disagree with the claim that a good syllabus requires a compelling narrative (p. 14) and that all teaching involves "teaching students how to read" (p. 90; emphasis in original). Yet the authors concede that given the bureaucratic constraints of institutional and departmental guidelines and deadlines under which syllabuses are written and courses are designed, "thinking of the syllabus as a space for understanding your teaching practice will...make it harder to write" (p. 17). Writing the syllabus as a vital teaching document is a challenge that not everyone will be willing or able to take on, especially in the context of a global pandemic; contingent faculty, in particular, may not have the time or freedom to engage in this kind of work.

But for those who want to make the most of their syllabuses, the authors provide a systematic, yet playful approach, addressing policies and procedures ("clock and calendar"), reading lists and assignments, giving feedback, and the importance of reflective teaching (they urge teachers to keep a "secret second syllabus" or teaching journal). The chapter on policies and deadlines contains a deft discussion of inclusion that invokes principles of UDL (Universal Design for Learning), explaining how "a pedagogy of inclusiveness... aims to be unremarkable" (pp. 31-32), and examining how policies of accommodation can in practice fail quieter students (p. 32). Similarly, their nuanced exploration of the sounds and silences of the classroom movingly illuminates the complexities of teaching: their analysis of the types of student participation and silence is helpful to anyone who assigns participation grades.

While acknowledging that the syllabus is in part a legalistic document, the very style of the book challenges the assumption that a syllabus must therefore be written in legalese. They refer to the expansive reading lists of graduate courses as "banquets" from which students feast and suggest that we treat feedback as nourishment for our students, asking if we are giving our students protein or mere sugar (p. 131). Similarly, the recurring musical analogies (a book on jazz improvisation in their short but rich list of references resonates throughout the book) highlight the creative potential of the syllabus to reanimate one's teaching. The figurative language of the book offers an intentional departure from the "technocratic" language common in educational research as they caution readers, "danger: another metaphor ahead" (p. 58). In this way, Syllabus differs from the research-heavy and useful but sometimes dull tomes on teaching (such as those in the popular Bedford/St. Martin's series), but neither does it fit entirely with the inspiring and largely anecdotal teacher-hero narratives usually authored by white men (a perspective that unfortunately informs some serious omissions in this book, as discussed below). As purposeful and enjoyable as the figurative language is, by the second half of the book such language seems excessive, such as when a classroom 
community is referred to in the same sentence as a village green and a shared office photocopier (p. 160). However, this is a minor quibble in what is otherwise a stylistically enjoyable read.

Other shortcomings of Syllabus may be attributable to the authors' institutional context at a small private college: the book has little to say about how teaching large-enrollment classes with teams of TAs, for instance, constrains course design and the timeliness and quality of feedback. Including more examples of syllabuses from other courses, disciplines, and institutional contexts (building on the syllabuses by famous teachers like Barack Obama and Gloria Anzaldua that are included) would enrich and anchor Germano and Nicholls' discussion and provide helpful models.

However, a more troubling omission, particularly for a recent publication, is the neglect of gender and racial politics. With diversity statements a requirement of most faculty job applications, not addressing how to create more inclusive syllabuses and courses is a serious oversight. In discussing reading lists, the authors observe that our syllabuses serve for many students as stand-ins for entire disciplines, but other types of representation (such as gender and race) are not mentioned, despite the fact that including diverse readings lists and data sets on the syllabus and assignments is one way teachers can challenge exclusionary and oppressive knowledge practices. The authors mention "the social and political force" (p. 25) of the syllabus, but interpret this phrase narrowly, referring to the classroom as a community without acknowledging the over three decades of scholarship that challenges the notion of a homogenous classroom community (Alexander, 2016; Graff, 2006; Pratt 1987; Rytkonen, 2006). Discussing student-centered learning without addressing how our classrooms are gendered and racialized ignores how teachers and institutions can use the syllabus to create more equitable classrooms. Addressing curricular reform in the tradition of Dewey, the authors invoke the term "ally" and call for the classroom to be a place of "alliance" (pp. 186-87). In a book that pays such close attention to language and texts, using the term "ally" without acknowledging its more recent connotation-i.e., a privileged partner who challenges oppressive practices and supports disenfranchised and underrepresented people and groups-seems anachronistic. Through practices such as including our pronouns on our syllabus, teachers can champion sexual and gender diversity. Carefully considering how our own gendered and racialized identities inform our syllabuses makes us better teachers, and addressing this essential facet of contemporary pedagogy would make this book a far richer and more timely contribution to WAC/WID discourse and, more broadly, the pedagogical literature in higher education.

Despite these gaps, Germano and Nicholls sound an important call for scholars across all disciplines to think more about teaching and learning than just about our own disciplinary subject matter and to use the syllabus as a tool for doing this thinking. Long before the pandemic, the syllabus was becoming students' first point of contact with a course. The syllabus serves as an early-warning system for many students who use it to decide whether to enroll in or drop a course. If they do choose to take our course, the trusty syllabus serves as an indicator of the prior knowledge and skills students are required to have and how much time and effort they will need to invest. So to treat our own syllabus in a cursory fashion is to miss a key way of communicating with our students. But putting aside how students read (or don't read) our syllabus, Germano and Nicholl's book is a writing-to-learn manifesto for teaching premised on the assumption that in the process of writing our syllabus, we as teachers can discover how best to help our students learn. In the more recent context of emergency remote teaching during the COVID-19 pandemic, when many of us have felt overwhelmed and disconnected, Syllabus reminds us that teaching is "one of the highest forms of our intellectual work" that is not "separate from the core of our scholarly lives but its animating force" (p. 17). To reconnect with this higher calling, we need look no farther than our own syllabus.

\section{References}

Alexander, Jonathan. (2016). Queered writing assessment. College English 79(2), 202-205.

Gannon, Kevin M. (2020). Radical hope: A teaching manifesto. West Virginia University Press. 
Graff, Gerald. (2009, 13 January). It's time to end "courseocentrism." Inside Higher Ed. https://www.insidehighered.com/views/2009/01/13/its-time-end-courseocentrism

Pratt, Mary Louise. (1987). Linguistic utopias. In Nigel Fabb, Derek Attridge, Alan Durant, \& Colin MacCabe (Eds.), The linguistics of writing: Arguments between language and literature (pp. 48-66). Manchester University Press.

Rytkønen, Helle. (2006). Whose knowledge? How race, class, religion, and gender intersect and interfere with "our" intellectual community. In Nancy G. Barron, Nancy Maloney Grimm, \& Sibylle Gruber (Eds.), Social change in diverse teaching contexts: Touchy subjects and routine practices (pp. 43-54). Peter Lang.

\section{Notes}

${ }^{1}$ The authors use the term "teachers" to avoid excluding or stigmatizing contingent faculty.

${ }^{2}$ Both "syllabi" and "syllabuses" are correct plural forms of syllabus, but rather than use a Latin conjugation ("syllabi") for what Germano and Nicholls point out was originally a Greek word, I have opted to use "syllabuses" here.

\section{Contact Information}

Andrea Williams

Associate Professor, Teaching Stream

Writing \& Rhetoric, Innis College

University of Toronto

Email: al.williams@utoronto.ca

\section{Complete APA Citation}

Williams, Andrea. (2022, February 18). A review of Syllabus: The Remarkable, Unremarkable Document that Changes Everything. Across the Disciplines, 18(3/4), 364-367. https://doi.org/10.37514/ATDL.2022.18.3-4.09 